\title{
Stensalmer
}

\section{- selvforhold og parallelisme i Salmernes Bog belyst ud fra Günter Bader og Paul Ricoeur}

\author{
Lektor dr.theol. \\ Carsten Pallesen
}

\author{
Oh harp and altar, of the fury fused \\ (How could mere toil align thy choiring strings!) \\ Terrific threshold of the prophet's pledge \\ Prayer of pariah, and the lover's cry, - \\ Hart Crane: "To Brooklyn Bridge"
}

Tilegnet Günter Bader

Abstract: The article, "Petrified Psalms: Self-relation and parallelism,
in the Book of Psalms in the light of Günter Bader and Paul Ricoeur",
presents two systematic readings of the Book of Psalms: Günter Bader's
Psalterspiel 2009 addresses the Book of Psalms as a whole, while Paul
Ricoeur offers an interpretation of Psalm 22 in the context of his in-
tertexual reading of the Passion in St.Mark and within the symbolic
network of the Biblical texts. In each of the two different approaches,
the article adresses the question about divine self-relevation: the Name
of God, in Ex 3:14 ("I am who I am") and human self-relation as it is
accentuated in a biblical formula of self-presentation: "I am poor" (ani/
aani). The article addresses the putative impact of biblical parallelism
and self-presentation on modern philosophy of subjectivity in Herder
and German idealism, classical strucuralism in Roman Jakobson and
post-structuralism in Jacques Derrida and Gilles Deleuze. Leaning on
Winfried Menningshaus and Bader it is argued that the Psalms have a
role of a vanishing or repressed mediator for philosophy of subjectivity.
This function is captured by the romantic metaphor 'petrified psalms'.

Keywords: Günter Bader - Paul Ricoeur - poetic parallelism - self theology of the Name - infinite reduplication - post-structuralism German idealism.

I de jødiske og kristne traditioner har Davids Salmer været en kilde til fordybelse og reformation af den individuelle og kollektive fromhed. Jesu og Paulus' salmebog er ikke bare det mest citerede skrift 
i Det ny Testamente, men de synoptiske passionsberetninger kan ifølge Paul Ricoeur betragtes 'fortolkende fortællinger' af især Salme $22 .{ }^{1}$ Elementer som gennemboringen af hænder og fødder, terningekast, delingen af klæderne og gudsforladthedens råb "Min Gud, min Gud, hvorfor har du forladt mig" er citater herfra, men også salmens struktur, spillet mellem individuel klage i første del og omslaget (S1 $22,22 \mathrm{~b}$ ) i form af løftet om universel lovsang, der omfatter døde og levende, fjender og venner, danner forlæg for passionsfortællingernes teologiske fortolkning. Det underliggende kerygma er sætningen "menneskesønnen forrådt", som det artikuleres narrativt i Markusevangeliet, og som Ricoeur forstår i forlængelse af det theologoumenon, der bestemmer den gammeltestamentlige fiktionsprosa. Ifølge Robert Alter er denne fortællekunst (midrash) bestemt af en teologisk modsigelse mellem Guds planers uafvendelighed på den ene side og menneskets uforudsigelighed på den anden. Guds planer lykkes ikke på trods, men $i$ kraft af menneskets genstridighed og modplaner ( $\mathrm{Ri}-$ coeur 1995, 182). Således er også “menneskesønnen forrådt” indskrevet $\mathrm{i}$ en apokalyptisk fortolkning, hvor fornægtelse og forræderi er tegn på gudsrigets frembrud. Klagesalmens (implicitte) kristologiske theologoumenon (gudsforladthedens urlidelse) er ifølge Ricoeur den ædelsten, som er tildækket af andre stemmer i psalteret, der bekræfter forskellige gammeltstamentlige teologier, hvis gyldighed klagen udfordrer.

Salmernes Bog udgør således en poetisk midte eller bro mellem Sinai- og Kristus-åbenbaringen. Den daglige og natlige omgang med psalteret var for Augustinermunken Martin Luther den afgørende impuls til hans evangeliske gennembrud. Gerhard Ebeling har vist, hvordan Luthers tidlige salmeudlægninger er en trædesten for den reformatoriske forståelse af lov og evangelium, bogstav og ånd hos Paulus. ${ }^{2}$ Mens den narrative fiktionsprosa spiller sammen med Tora-åbenbaringen i GT og med Kristusåbenbaringen i NT, tilhører psalterets poetisk musikalske genre en tredje kategori, Skrifterne, en brokkasse, der allerede i den jødiske tradition blev anset for at være inferiør sammenlignet med hovedteksterne: Loven og Profeterne.

I vor tid kan Salmernes Bog forekomme endnu mere antikveret end dengang metaforen stensalmer blev udbredt blandt tyske protestantiske teologer for at betegne romantikkens følelse af et tab. Beundringen for romanske kirkebygninger som forstenede salmer forstærkede følelsen af tabet af et gyldigt sprog for det absolutte. På Friedrich

1 Paul Ricoeur, "Interpretive Narrative", Figuring the Sacred (New York: Fordham 1995), 181-199.

2 Gerhard Ebeling, Evangelische Evangelienauslegung. Eine Untersuchung zu Luthers Hermeneutik (1942) (Darmstadt: Wissenschaftliche Buchgesellschaft 1962). 
Schleiermachers tid blev religionen som lære, dogme, fortælling og kult blandt de dannede afløst af taler efter forbillede i Johannesevangeliets afskedstaler. Fra Schleiermachers Reden (1799) til Søren Kierkegaards Opbyggelige Taler (1849) antager religionen nu form af tale, der skjuler, at dens medium først og fremmest er skrevne tekster. ${ }^{3}$ I kølvandet på nutidig strukturalistisk og poststrukturalistisk sprogfilosofi bliver skriften imidlertid omfattet med en ny opmærksomhed. Den romantiske tabserfaring har skærpet opmærksomheden om psalterets formelle træk så som poetisk parallelisme og akrostik og mindet om den traditionelle forståelse af bogen, som fremgår af den latinske betegnelse psalter et musikinstrument, Davids harpen, der primært er samlet og overdraget til lasningen (jf. Sl 1). I denne indsigt ligger en samtidighed med "ophørsmusikken" i Salme 137 "Ved Babylons flo$\mathrm{der} / \mathrm{sad}$ vi og græd /når vi tænker på Zion./I landets popler/ hængte vi vore harper."

I denne artikel vil jeg først fremhæve det underliggende og særdeles stærke bånd mellem de bibelske salmers altdominerende poetiske parallelismer på den ene side og de refleksive fordoblinger, som den tidlige tyske romantik og idealisme har udforsket som subjektivitetens negativitet på den anden. Denne sammenhæng træder særligt tydelig frem i lyset af Roman Jakobsons klassiske strukturalisme og i poststrukturalismens forskydninger heraf. Ad denne omvej over skriftens formelle træk, parallelisme og akrostik, er det ifølge Günter Bader muligt at formulere spørgsmålet om Guds navn vis à vis det klagende og bedende menneskes selvforhold. En Salmernes teologi er således kun mulig ad omvejen over tekstens systemiske aspekter og kun som kristologi i en præcis betydning, som indholdsmæssigt knytter til ved klagesalmen. Den samme pointe fremgår af Ricoeurs udlægning af Markuspassionen, hvor en semiotisk narratologi kombineres med Robert Alters litterære kritik (Ricoeur 1995, 181-182, 187-191).

På baggrund af en præsentation af Ricoeur og Bader vil jeg give en mere indgående redegørelse for forholdet mellem akrostik, parallelisme og selvåbenbaringsformlen ani aani (jeg er fattig) hos Bader. Denne gentagelse (ani aani) danner et menneskeligt modstykke til Guds selvåbenbaringsformel, "jeg er den jeg er”, Guds navnet (2 Mos 3,14-15), som i Baders udlægning spiller sammen med de stemmer, der taler i salmen. Psalterets virkningshistorie som musikalsk poetisk medium for overgangen mellem loven (Toraen) og evangeliet (Passionen) kan udstrækkes til bygningen af romanske kirker som forstenede salmer. Til afslutning peger artiklen på Hart Cranes digtcyklus

3 Günter Bader, "Geist und Buchstabe - Buchstabe und Geist, ausgehend von Schleiermachers Reden 'Über die Religion”, Internationales Jahrbuch für Hermeneutik 5 (Tübingen: Mohr Siebeck 2006), 95-140. 
The Brigde (1933), hvor stålwirerne i Brooklyn Bridge er en metafor for psalterets affektive realitetsfordoblinger. ${ }^{4}$

\section{Salmernes teologi?}

Den franske filosof Paul Ricoeur (1913-2005) har gennem hele sit forfatterskab beskæftiget sig med de bibelske tekster som et symbolsk netværk i sammenhæng med forsøget på at udfolde en hemeneutisk teori om selvet. Den bibelske benævnelse af Gud, forholdet mellem navnets åbenbaring (2 Mos 3, 14) og de forskellige partielle benævnelser, som fremgår af de øvrige bibelske genrer, danner et teologisk modstykke til den moderne (ateistiske) filosofis spørgsmål om subjektivitet og selvforhold. ${ }^{5}$ René Descartes' cogito, som det gentænkes af Immanuel Kant, Johann Gottlieb Fichte, Georg Wilhelm Friedrich Hegel og Edmund Husserl, markerer positioner i den filosofiske tradition, som Ricoeur selv indskriver sin tænkning i. De to uforenelige poler: åbenbaringen af transcendensen og det autonome subjekt tangerer hinanden i sproget, uden at spændingen mellem åbenbaring og selvbevidsthed ophæves. I dette spændingsfelt udfolder Ricoeur sin bibelske hermeneutik eksempelvis i værker som Thinking Biblically (1998) eller tekstsamlingen Figuring the Sacred (1995). ${ }^{6}$ Med Ricoeur angives den religionsfilosofiske ramme for min anden indgang til temaet: den tyske professor i systematisk teologi Günter Bader ( $f$. 1943-). "Prolegomena til en Salmernes Teologi" lyder undertitlen til hans Psalterium affectuum palaestra (1996), og Psalterspiel fra 2009 er en "skitse til en psalterets teologi". Baders salmelærdom omfatter den filologiske, musikalske, poetiske, ikoniske og teologiske virkningshistorie, som han gentænker ud fra en moderne religionsfilosofisk kontekst i feltet mellem strukturalisme og post-strukturalisme. Denne kontekst trækkes navnlig op i Die Emergenz des Namens (2006). ${ }^{7}$ I artiklen "Navn og parallelisme" har Bader givet en sammenfatning af forholdet mellem navneteologi og poetisk parallelisme. ${ }^{8}$

4 I etymologien låner brobyggeren navn til præsten pontifex maximus, den største brobygger. Jf. Michel Serres "IV. Ponts saints", L'art des Ponts. Homo pontifex (Paris: Le Pommier 2006), 187-213.

5 Ricoeur,"Naming God", Figuring the Sacred (1995), 217-235.

6 André LaCocque and Paul Ricoeur, Thinking Biblically (Chicago: Chicago University Press 1998).

7 Günter Bader, Psalterspiel. Skizze einer Theologie des Psalters (Tübingen: Mohr Siebeck 2009); samme, Die Emmergenz des Namens. Amnesie. Aphasie. Theologie (Tübingen: Mohr Siebeck 2006); samme, Psalterium affectuum palaestra. Prolegomena zu einer Theologie des Psalters (Tübingen: Mohr Siebeck 1996).

8 Günter Bader, "Navn og parallelisme", DTT 74/3 (2011), 196-216. 
Hverken Bader eller Ricoeur udkaster en Salmernes teologi, ligesom de er tilbageholdende med at slutte direkte fra den bibelske betoning af jeget til det jeg, der ligger til grund for den moderne subjektfilosofi. De lægger begge vægt på formelle træk og strukturer som den moderne sprogfilosofi, litteraturteori og eksegese har fremdraget, og som afspejler sig i virkningshistorien.

Ricoeur behandler således salmegenren som én af flere stemmer i den bibelske polyfoni, der cirkulerer om Jahve-navnet som deres forsvindingspunkt (Ricoeur 1995, 217-235). I Tora'ens foreskrivende genre taler Jahve i førsteperson, mens han i urhistorierne og historieværkets fortællende genrer er en aktant, der figurerer i tredjeperson som hærskarers Herre, historiens helt. I profetlitteraturen taler Jahve gennem profetoraklets fordoblede jeg, "Så siger Herren", og i visdomslitteraturen er transcendensen en anonym symbolsk orden. I spillet mellem disse stemmer og personlige pronominer skiller hymnens og klagens lyriske genrer sig ud ved jegets og duets intensiverede positioner. Navnets åbenbaring (2 Mos 3, 14) udgør ifølge Ricoeur en genre for sig. ${ }^{9}$ Navnets hemmelighed er således forsvindingspunktet for de partielle skematiseringer af transcendensen i historien og naturen, der benævner Gud ud fra den menneskelige pol, spørgsmålet hvem er jeg/vi selv? Det Gamle Testamente kan således opsummeres i spørgsmålet: "hvem er Jahve?” Fortællingen er et delvist svar herpå, der afgrænses af gudsforladthedens og transcendensens afgrunde, der især artikuleres i de poetiske genrer (Ricoeur 1995, 185). Mellem tetragrammets negative pol og den klagende og lovsyngende pol åbner transcendensens afgrunde sig som havdyb, der råber til havdybet "Abyssus ad abyssum vocat" (Sl 42,8 Vulg 41,8; Bader 2009, 402). Salmen er en bro over urolige vande, der som Brooklyn Bridge i Hart Cranes digtcyklus The Bridge "whispers antiphonal in azure swing."10 I Salme 22, Min Gud, min Gud, hvorfor ... træder det individuelle potenserede "jeg" frem i klagen over gudsforladtheden og i betoningen af min Gud. Den bibelske poesi passerer gennem jegets nåleøje (Bader 2009, 390) og henvender sig i klage som anklage og bøn til Guds person, navn eller "du". Den sproglige analyse spiller sammen med det teologiske tema: gudsforladthed. Hvorfor og hvorlænge spørges der om lidelsen og det ondes væren og varen. I denne klagende spørgen ("questioning lament") finder Ricoeur det afgørende theologoumenon, som den døende Jesus på korset ikke blot citerer, men iklæder sig: "The dying Jesus clothes his suffering in the words of the psalm,

9 Ricoeur,"From Interpretation to Translation", Thinking Biblically (1998), 331361.

10 Hart Crane, "VIII. Atlantis" (The Bridge) The Complete Poems of Hart Crane (New York/London The Centennial Edition Liveright 2000), 108. 
which he wears, so to speak, from the inside." ${ }^{\prime 11}$ Klagesalmen protesterer implicit mod en tolkning af lidelse som straf og gengæld, hvormed den deuteronomistiske skole (neurotisk gentagende) forsvarer Jahves retfærdighed over for kristologiens transmoralske excess. I kristologien forbindes klagesalmen med den retfærdige, der lider (Job) og med sangene om Herrens lidende tjener (Jesaja 53). I disse tekster artikuleres en lidelse uden henvisning til skyldens eller uskyldens økonomi, og således adskiller klagesalmen sig afgørende fra bodssalmen, der var yndet i den protestantiske fromhed (Ricoeur 1998, 226). Klagen baner vejen for den lidende Guds kristologi. I den kristne passion ophøjes gudsforladthedens urlidelse til det centrale gudsprædikat.

\section{Navneakrostik og parallelisme}

Salmernes Bog er ifølge Bader bestemt ved to træk, dels at den er en navnebog, dels at den forløber i parallelle linjer (Bader 2011, 200). I dette perspektiv læser han Salmernes Bog som ét værk, idet han sætter parentes om de spørgsmål om salmens "Sitz im Leben", om salmernes forskellige genrer og om de redaktionelle diskussioner om, hvordan de 150 salmer er grupperet, der siden Herman Gunkel og Sigmund Mowinckel har domineret den historisk-kritiske forskning. I stedet fremhæver Bader spillet mellem skrift og tale, den poetiske parallelisme og navne- eller alfabet-akrostik. De systemiske træk skærper blikket for psalterets filosofiske og poetiske refleksionspotentiale og for den systematisk teologiske tematik: Guds navn, treenighed og kristologi. Nogle tilfældige nedslag kan tjene som illustration af den poetiske parallelisme, ${ }^{12}$ "men har sin glæde ved Herrens lov/og grunder på hans lov dag og nat" (Sl 1,2); "Jeg var nær snublet/mine fødder var nær gledet" (S1 73, 2). ${ }^{13}$ Parallelismen er ganske vist gennemgående, men den adskiller sig fra en anden beslægtet figur, merismen, "en ting har Gud sagt/ to ting har jeg hørt" (Sl 62, 12). For denne figur, der optræder i nogle akrostiske navnehymner, peger Bader på

11 Ricoeur, "Lamentation as Prayer", Thinking Biblically (1998), 211.

12 Bader (2009), 396-409; se tillige Allan Rosengren, "Parallelismer i Det Gamle Testamente", DTT 64:1 (2001), 1-15; og med inddragelse af Roman Jakobsons teori, Adele Berlin, The Dynamics of Biblical Parallelism. Revised and Expanded (Grand Rapids, MI / Cambridge: Eerdmans 2008).

13 Som paradigme for parallelismen fremhæver Robert Alter 1 Mos 4, 23-24: "Og Lemek sagde til sine hustruer: 'Ada og Zilla, hør min røst, Lemeks hustruer, lyt til mine ord: En mand har jeg dræbt for et sår, en dreng for en skramme. Blev Kain hævnet syvfold, så hævnes Lemek halvfjerdsindstyve gange'.” Se Robert Alter, "The Dynamics of Parallelism", The Art of biblical Poetry (1985) (New York: Basic Books 2011), 6-12. 
Salme 113 (Sl 8), mens en anden type gentagelse uden tohed optræder i Salme 29, der er mønstereksemplet på en akrostisk navnesalme, hvor navnet bestemmer linjebruddet, og hvor han finder gentagelse, men uden tohed. Poetisk parallelisme kræver, at merismen danner linjer, eller at linjen danner merismer (Bader 2011, 201-202). Robert Lowth, der grundlægger teorien om poetisk parallelisme med værket De sacra poesi Habreorum (1753), giver i 1779 følgende lakoniske definition: "The Correspondence of one Verse, or Line, with another, $I$ call Parallelism" (Bader 2009, 398). Bredt forstået fremkalder den en suggestiv sproglig energi, der tager til, når den i Salmerne kombineres med navnets intensitet og frekvens. Alene ved hyppigheden af navnet er Salmerne ifølge Bader uomgængeligt teologi. "Jah" i hallelu-jah er den korte version af tetragrammet Jahve. Bader kombinerer den poetiske parallelisme med navnets tautologiske gentagelse: "jeg er, jeg er” (2 Mos 3,14), og navnet viser sig således selv at være en parallelisme en miniature (Bader 2011, 212-213).

Parallelismen er som antydet et alt overskyggende træk ved den hebraiske poesi og åbner betydningslag, der ikke kan oversættes, eftersom denne gentagelse også beror på skriftens optiske og plastiske fremtræden. Læsbarheden kan ikke høres, synges, men kun ses i det hebraiske skriftbillede, som ifølge Bader er en helt afgørende dimension i de såkaldte akrostiske salmer. 'Akrostisk' betyder, at begyndelsesbogstavet i hvert vers følger alfabetet: alef, bet, gimel, dalet... eller følger radikalerne i en version af gudsnavnet. I Salme 29 viser det hebraiske skriftbillede, hvordan de tværgående parallelismer gennemskæres af den lodrette navneteologi (Bader 2009, 421). Temaet er Jahves stemme, der sammenlignes med naturfænomener. Opdagelsen af parallelismen hænger således ifølge Bader på akrostikken, "sie ist der harte Kern der hebräischen Dichtung." (Bader 2009, 424). ${ }^{14}$ Jacques Derridas kunstterm différance, hvor forskellen mellem e og a er uhørligt, men synligt, giver et fingerpeg om spillet mellem syn og hørelse, der yderligere forstærkes, når man medtænker, at den førmasoretiske skrift ikke var vokaliseret, men alene angav konsonanter (radikaler). Derridas grammatologi er en påmindelse om stemmens fortrængning af skriften i den indoeuropæiske (sprog)filosofi fra Platon til Ferdinand Saussures og Husserl. Alfabetakrostikkens formalisme indeholder et tilsvarende modtræk til fono-logo-centrismen, der ifølge Bader betyder, at alfabetet fratages sin traditionelle billedlige lighed og betydningsreferencer, som eksempelvis, at $\mathrm{A}=$ alef = okse og ligner en sådan, at $\mathrm{B}=$ bet betyder og ligner et hus, eller at radikalen for $\mathrm{G}=$ gimel betyder og ligner en kamel (Bader 2009, 172). Akrostikken understreger på den ene side lydskriftens abstraktionsydelse

14 Navne-krostikken er en "lodret-fra-oven-teologi" (Bader 2009, 423). 
i forhold til piktogrammer og hieroglyffer, men påpeger samtidigt på den anden side, at skriften ikke forsvinder ind $\mathrm{i}$ talens, stemmens indre selvnærvær, som et blot udvendigt supplement hertil. Sammen med billed- og navneforbud blokerer skriftens selvstændiggørelse fra indholdssiden for, at transcendensen kan genindskrives $\mathrm{i}$ immanensen, hvilket er en afgørende teologisk funktion. Navnet (2 Mos 3,14) vogter denne grænse inden for den bibelske betydningsøkonomi, idet navnet og navne generelt unddrager sig sprogets bøjninger (Bader 2009, 418). Akrostikken synliggør skriftens uoversættelige lydløse lodrette systemer, mens parallelismens semantiske skyttel væver sine gentagelser og vokaler. Således frembringer psalteret en unik flerdimensionel sproglig tekstur, hvis virkningshistorie har kaldt på alle kunstarter og intellektuelle resourcer.

Titlen på Baders artikel "Navn og parallelisme" angiver, hvordan parallelismen er medbestemt af navnets teologi og omvendt. Parallelisme dannes i sproget, når navnet (Guds) falder ind i det på samme måde, som de koncentriske cirkler, der dannes, når sten kastes i vandet (Bader 2011, 196). Men navnets teologi hører, trods frekvens og intensitet, ikke først og fremmest til salmelitteraturen, men til Loven (2. Mos 3,14; 15,3; 20,1; Bader 2011, 200). Disse steder spiller ingen rolle i Salmerne, hvorfor hyppigheden af navnet her kan antages at være ren dekoration (Bader 2011, 201). Derfor er det ikke oplagt at kombinere parallelisme og navneteologi. Navneteologiens emergens $\mathrm{i}$ parallelismen, altså i salmelitteraturen, er temaet for Baders førnævnte artikel.

\section{$\&$ - en anatomisk ekskurs}

I sangen "I\&I" refererer Bob Dylan"15 ikke alene til klagesalmes selvåbenbaringsformel ("jeg fattige"/ "ani aani") og til "some righteous king who wrote psalms", men også til Tora- og navneteologien: "no man sees my face and lives". Dylan tilhører den angloamerikanske litteratur, hvis overlegenhed ifølge Gilles Deleuze består i, at "er" erstattes med "og". 16 Den sidestillede fordobling kan oplagt føres tilbage til den bibelske parallelisme, der også kendes fra prosaen i form af det såkaldte "konsekutive $o g$ ", som er bevaret i oversættelser af

15 Bob Dylan, Infidels (1989).

16 Gilles Deleuze, "Bartleby; or, The Formula", Essays Critical and Clinical (London: Verso 1998), 68-90. Deleuze \& Claire Parnet, "Dialogues 'On the Superiority of Anglo-American Literature”" Dialogues II (New York: Columbia University Press 1987), 27-56. Bruno Liebrucks,"Und". Die Sprache Hölderlins in der Spannweite von Mythos und Logos, Sprache und Bewusstsein Bd.7 (Bern: Peter Lang 1979). 
evangeliernes fortællestil "og det skete ...". 'To be and not to be', som Francis Bacon har gjort til en ledetråd for sit maleri, er et eksempel på en agrammatisk formel, som kunne være en amerikansk Hamlet værdig. Mens den europæiske Hamlet tænker ånd som dødningehoved (Poor Yorick!) eller i Hegels gengivelse "Geist ist Schädelkopf" 17 , anfører Deleuze som et andet fortrin, der udmæker den amerikanske litteratur over for den engelske eller franske, at dødningehovedet her er erstattet med ryghvirvlen: "A wall of loose uncemented stones (...). Not a skull but the vertrebral column, a spinal chord."18 Netop denne analogi bruger Bader om psalteret i forordet til Psalterspiel, hvor han bemærker, at de latinske salmecitater, der var sat i petit og anbragt i midten i skriftbilledet i det foregående værk, Die Emergenz des Namens, kan anskues som fossilerede rester af en ryg-hvirvel, der engang har været intakt, og som han med den nye bog håber at kunne rekonstruere (Bader 2009, "Vorwort").

\section{Navn og stemmer}

Med Derrida peger Bader på skriftens modstand imod en kristologisk (fono-logo-centrisk) oversættelse af Salmernes fremmede skrift og tale. Dermed ikke sagt, at Salmerne ikke kan oversættes, men at det har sin pris: når akrostikkens lodrette akse udviskes, går navnets bogstavelige transcendens tabt. Teologiens uomgængelighed melder sig derfor ifølge Bader i form af navnets emergens. Ved teologi forstår han nemlig navnets teologi såvel i den jødiske som i den kristne tradition. I den jødiske tradition betegner navnet transcendensens hemmelighed ("jeg er den jeg er"), mens treenigheden ifølge den kristne tradition er det åbenbarede navn, der eksempelvis nævnes ved dåben: “i Faderens, Sønnens og Helligåndens navn”. Treenigheden er ifølge en oldkirkelig tradition udledt af spillet mellem stemmerne i psalteret (Bader 2009, \$9). Én af disse er Guds fremmede og vilde stemme i Sl 29, der får linjer til at danse og spalter barken af træerne i Libanon, og som Hegel i sin æstetik citerer som udtryk for den hebraiske poesis sublimitet (Bader 2009, 420f). Hertil kan føjes dels den egne fremmede stemme, der citeres i visse salmer $(139,11$; 73,15; Bader 2009, 377ff), dels den fremmede stemme som fremmed. Disse udgør tilsammen den flerstemmighed, der ifølge dogmehistorikeren Carl Andresen er en afgørende kilde til trinitetslæren i oldkirken (Bader 2009, 413). Trinitetslæren er følgelig den indretrinitariske "samtale",

17 G.W.F. Hegel, Phänomenologie des Geistes (Hamburg: Felix Meiner Verlag 1988), 222.

18 Deleuze (1998), 86; Bader (2009), 152. 
som Gud selv er i sine tre personer eller stemmer. Således er treenigheden identisk med sig selv gennem sin egen indre andethed. Salme 22 er paradigmet for den fremmede egne stemme, hvormed Gud i den anden person taler til sig selv: "Min Gud, min Gud..." ${ }^{19}$ For denne indretrinitariske selv-reference udviklede de nikænske fædre begreber som "autologos" (selv-ord) og "homoousia" (Bader 2011, 216). Theologia er oprindeligt et modbegreb til oikonomia, læren om den ydre treenighed, idet termen theologia var forbeholdt læren om den indre treenighed (Bader 2009, 7-8). Psalter-teologi er således ifølge Bader kun mulig som implicit "kristologi" forstået som selvreference (selvord) (Bader 2009, 411; 409-416), som Bader bl.a. ekspliciterer med spillet mellem den poetiske og den prosaiske pol i Roman Jakobsons sprogteori.

Til spændingsfeltet mellem navnet "jeg er den jeg er", der unddrager sig i en tautologisk selvreference, og det navn, der udtaler sig i spillet mellem stemmerne, føjer psalteret det menneskelige jegs selvpræsentation, der indeholder en dissonans, der derfor ikke er slet og ret tautologisk. Det markeres mindst 7 gange med den påfaldende selvåbenbaringsformel "ani aani". Meningen kan oversættes "Jeg er fattig", men effekten er et uoversætteligt minimalt rim, der svinger mellem to radikaler ayin og alef en tung (aa) eller let (a) udtale af vokalen a (Bader 2009, 390-396). Denne sprogligt afvigende eller agrammatiske formel forekommer kun i psalteret og kun disse 7 steder $(25,16 ; 40,18 ; 70,6 ; 69,30 ; 86,1 ; 88,16 ; 109,22$, og måske $116,10)$. Udtrykket er en fordobling, men ikke en tautologi som i den guddommelige selvåbenbaring $(2$ Mos 3,14). "Jeg er fattig" adskiller sig imidlertid også fra subjektfilosofiens absolutte jeg, som det eksempelvis og berømt formuleres med Fichtes såkaldte ur-jeg (jeg=jeg). Her mangler den afgørende differens, dissonans mellem alef og ayin. Klagens minimale dissonans indikerer lidelsens theologoumenon, som ifølge Bader og Ricoeur først anerkendes, når Gud bliver menneske (en lidende gud), og i denne bliven til overvinder den negative teologis tautologiske gentagelsestvang eller "deuterosis", som den iagttages i Femte Mosebog. ${ }^{20}$ Den forløstes sande sprog er ikke poesiens hvirvler og fordoblinger, men prosaens tvangfrie tale, og således skal salmernes teologi søges hinsides poesiens parallelismer (Bader 2011, 214). Jeg=Jeg er Fichtes formel for den "intellektuelle

19 Det fremgår især af Markuspasionen, som ifølge Ricoeur er en midrash over salme 22, der er formuleret som et modtræk til andre - bodsteologiske og herlighedsteologiske - stemmer i psalteret, som lægger op til en triumferende kristologi ( se note 1).

20 Ricoeur, "L' enchevêtrement de la voix et de l'écrit", Lectures 3 (Paris: Seuil 1994), 316. 
anskuelse", der i andre varianter udforskes i den tyske idealisme fra Kant til Hegel, og som den sidstnævnte kalder "selvrelateret negativitet”. Fordobling, selvreference og tautologi udgør centrale figurer i den spekulative tænkning fra Kant til Kierkegaard. ${ }^{21}$ Dieter Henrich har præget udtrykket "autonom negation" som betegnelsen for grundoperationen i Hegels logik, der ifølge Manfred Frank er nøglen til at forstå poststrukturalismen, navnlig Derridas term différance. ${ }^{22}$ Denne tolkning af idealismen står i centrum for debatten om subjektet hos ny-lacanianeren Slavoj Žižek, der dog til forskel fra Henrich og Frank understreger den kristologiske baggrund for Hegels logik. ${ }^{23}$ Med ordspillet "non/nom du père", faderens nej (Toraen) og faderens navn indskriver den lacanianske psykoanalyse sig i den jødiske navneteologi. Selvrelateret negativitet er således det fortolkningsperspektiv, som Žižek anlægger på Sigmund Freuds begreber om gentagelsestvang, der antages at konstituere cogitoet hos Descartes og Kant. Ifølge Jacques Lacan og Žižek er Freuds begreb om det ubevidste en teori om cogitoet læst i dødsdriftens perspektiv. ${ }^{24}$

Hegels variant af den intellektuelle anskuelse, den autonome negation, ophæver naturen i den absolutte ånds sfære. Den différance, der her sætter de forskelle, som ånden griber over, kunne illustreres med Guds "stemme" i Salme 29, hvorved affiniteten mellem åndsfilosofiens negativitet og Derridas Stemmen og fanomenet ville være understreget. ${ }^{25}$ (Natur)fænomenets tilsynekomst for intentionaliteten er krydset af stemmen, der er salmens tema, og af skriftens underliggende system, der trænger sig på i form af navneakrostikken. Skrift og stemme bryder således fænomenets enhed og idealitet, og dermed brydes bevidstheden op i en polycentrisk flerhed, som Hegel opfanger med sit åndsbegreb: "begrebet om en uendelighed,

21 Se Winfried Menningshaus, Unendliche Verdopplung. Die frühromantische Grundlegung der Kunsttheorie im Begriff absoluter Selbstreflexion (Frankfurt/M.: Suhrkamp 1987), 7-27, 166ff.

22 Manfred Frank, “'Différance' und 'autonome' Negation'. Derridas Hegel-Lektüre”, Das Sagbare und das Unsagbare, (Frankfurt/M.: Suhrkamp 1990), 446-470. 23 Slavoj Žižek, "Descartes and the Post-Traumatic Subjekt", Filosofski Vestnik 29/2 (2008), 9-29.

24 "If you look at the very core of psychoanalytic theory, of which even Freud was not aware, it's properly read death drive - this idea of beyond the pleasure principle, self-sabotaging, etc - the only way to read this properly is to read it against the background of the notion of subjectivity in German idealism" S.Žižek, "Liberation Hurts: An Interview with Slavoj Žižek", http:/levans-experientialism.freewebspace. com/rasmussen.htm (2003) (besøgt 8. juni 2011). Se tillige Mads Peter Karlsen, The Grace of Materialism (København: Publikationer fra Det Teologiske Fakultet 2010), 179, samt samme, "Krop og psykoteologi" i Kroppens Teologi, red. Johanne Stubbe Teglbjerg og Kirsten Busch Nielsen (København: Forlaget Anis 2011), 37-60.

25 Jacques Derrida, La voix et le phénomène (Paris: PUF 1967). 
der realiserer sig i selvbevidsthedens enhed i fordoblingen" (Hegel 1988, 127). Selvbevidstheden er følgelig en "mangesidig mangetydig sammenfletning". ${ }^{26}$ Identiteten tænkes her som en spekulativ realitetsfordoblende aktivitet, der spænder fra transcendensens "jeg er den jeg er" (Guds navn) til den endelige menneskelige erfaring "ani aani” (jeg er fattig). På lignende måde er parallelisme, selvåbenbaring og navneåbenbaring tre sammenslyngede spor, der krydses i psalteret og i særdeleshed i klagesalmens accentuering af det bedende og lovsyngende jeg. I henvendelsens selvoverskridelse, "min Gud min Gud..." foregriber klagen i første del af Salme 22 lovsangen i salmens anden del, og i (løftet om) lovsangen klinger klagen (og anklagen) fortsat med som en resonnans i lovsangen. Omslaget fra klage til lovsang i Salme 22 er psykologisk umotiveret. ${ }^{27}$ Det har ført til teorier om, at der er tale om en sammenstykning af to forskellige salmer, og til antagelsen af en kultisk kontekst, hvor et frelsesorakel fra en præst tænkes at begrunde omslaget. Ifølge Ricoeur er Salme 22 imidlertid et juvelskrin, der først åbner sin skat, når gudsforladthedens theologoumenon i kristologien bliver artikuleret som Guds egen lidelse og død (Ricoeur 1998, 227). Det sidste er endnu ikke muligt indenfor hverken de narrative eller profetiske traditioners teologi, som udfordres af klagesalmens (an-)klage hinsides skyld og uskyld. Klagens dissonans danner modvægt til en selvreferentiel identitet, cogito ergo sum, der forstår subjektet som moralens og erkendelsens urokkelige fundament, men miskender det traume, der konstituerer det kristne subjekt. Den traumatiske kerne ligger således ifølge Bader i accentforskydningen fra subjektfilosofiens "jeg = jeg" (Fichte) til klagesalmens "ani aani" (jeg er fattig). Fattigdommen markeres som det menneskelige vilkår, der (proleptisk) ophæves i henvendelsens selvåbenbaring: $\min$ Gud.... Negationen, som kristologien bringer til orde, er en fordobling i sproget, der samtidig negerer en naturalistisk forståelse af subjekt og selv ud fra selvopholdelse og immanens. Naturalismen fikserer bevidstheden på en antaget drift til lyst og lykke, men ekskluderer det "hinsides lystprincippet" (fattigdom, depression, gentagelses-tvang og dødsdrift), som den bibelske klagesalme og visdom låner stemmer.

26 Dette er også grundtanken i Ricoeurs teori om selvet, der er indeholdt i titlen "én selv som en anden" (Oneself as Another). Jf min, Handlen og varen. Paul Ricoeurs polytetiske reflektionsteori (København: Publikationer fra Det Teologiske Fakultet 2010), 35.

27 Ricoeur,"Lamentation as Prayer" i Thinking Biblically (1998), 221. 


\section{Stensalmer}

Psalterets receptionshistorie udfolder et spil mellem flere betydningshorisonter, som Bader behandler i bogen Psalterspiel. Spillet mellem filosofi, arkitektur, ikonicitet, poetik, musik og teologi aftegner sig i den måde, de 150 salmer er blevet læst, samlet og genlæst på som én bog i den jødiske og kristne virkningshistorie. Betegnelse psalter (=strengeinstrument) optræder først sent i den latinske tradition ved overgangen til nyere tid, hvor Salmerne ikke længere har den samme betydning, som de har haft for kirkefædrene, som autologos, treenighed og himmelsk lovsang, men hvor de filosofiske, æstetisk musikalske og poetiske betydningsstrenge træder i forgrunden. Den betydning, som oldkirken og de gammeltestamentlige forfattere har tillagt Salmernes Bog som fuldbyrdelse af teologiens selv-ord og som treenighedens stemmer, er os ikke mere tilgængelig. Men denne tabserfaring, bevidstheden om Salmernes forsvinden som theologia, er blevet formuleret ved overgangen til nyere tid. Salmerne gendigtes nu som kirkesange. Således oversætter og fortolker Martin Luther Davids Salmer ud fra bevidstheden om den kategoriske forskel mellem de bibelske salmer og hans egne gendigtninger som andenrangs "sange" (Kirchen-Lieder).

Ifølge Luther er Salmernes Bog primært "bogstavsalmer", som har været undertrykte af den hævdvundne firfoldige allegoriske metodes aktualiseringshermeneutik. Det er ét af flere træk, der forbinder Luthers "destruktion" af den allegoriske hermeneutik med Derridas "dekonstruktion". ${ }^{28}$ Allegorien domesticerer skriftens gentagelser gennem analogier, der fører fra sensus litteralis til sensus allegoricus - tropologicus - anagogicus. Derved bringes det forestillingsmæssige indhold i fokus, mens skriftens intertekstuelle selvreference (sola scriptura) afsvækkes i henholdsvis troens allegoriske, moralens tropologiske og opbyggelighedens anagogiske repræsentationer. I den firfoldige metodes skopus bliver Guds retfærdighed ifølge Luther forstået som et krav, en lov, der fører til menneskets fordømmelse. Med Salmeforelæsningen 1513-15 vinder Luther en første afklaring af en alternativ forståelse af prædikatet Guds retfærdighed (Ebeling 1962). Den fremkommer ved eksklusivt at skelne mellem en bogstavelig og åndelig betydning, der svarer til den senere distinktion: lov/evange-

28 Se Jean-Luc Nancy, La Déclosion (Déconstruction du christianisme, 1) (Paris: Galilée 2005), 216. Nancys dekonstruktion af kristendommen omfatter desuden hovedværket Corpus (New York: Fordham University Press 2008) og senest L'adoration (Déconstruction du christianisme, 2) (Paris: Galilée 2010). 
lium. Loven og Kristus er ifølge Luther to møllesten, hvorimellem mennesket kværnes som kerner og avner. ${ }^{29}$

I spørgsmålet om Guds retfærdighed/iustitia dei var det ifølge Luthers senere udsagn "ordenes sammensætning" connexio verborum, der "åbnede paradisets døre" (Bader 2009, 81). Det drejer sig på et plan om den semantiske mening, men i en nutidig kontekst er det oplagt også at medtænke andre måske ubevidste semiotiske og grammatologiske niveauer af Luthers skriftforstålse (sola scriptura). Skriftens systemiske redundans, akrostik og parallelisme, er således et aspekt af erfaringen af lovens negativitet som syndens og dødsdriftens incitament. Men en sådan læsning møder modstand fra den af profeterne inspirerede deuteronomistiske teologi, der er den ideologiske ramme for den bibelske historieskrivning. Deuteronomismen forudsætter en moralsk verdensorden, der bærer mytens eller fortællingens økonomi, og som er paradigmet for historiefilosofiske og frelseshistoriske indordninger af det onde under Guds plan. Her er der ikke plads for at anerkende gudsforladthed som den urlidelse, der med Messiasforestillingen, Herrens lidende Tjener, Job og klagesalmen stiller krav om at blive løftet op til det centrale theologoumenon, som det sker med den kristne Passion. ${ }^{30 "}$ "Menneskesønnen forrådt" er som nævnt det kerygma, som i Markuspassionen fortolkes som tegnet på gudsrigets frembrud. ${ }^{31}$ Luthers "evangeliske evangelie-udlægning" (Ebeling, 1962) indebærer følgelig en tilbageføring (dekonstruktion) af analogierne ud fra det absoluttes egen selvfremstilling, der ifølge kristendommen finder sted på korset. Mytens (analoge) orden bliver her omvæltet ud fra gudsrigets nye (u) orden, og dette teologiske program begrunder, at Markuspassionen bliver en stadigt mere dunkel og uforståelig metafortælling, en ophævelse af fortællingen i fortolkningen..$^{32}$ l lyset af den nutidige filosofiske dekonstruktion af kristendommen hos Derrida og Jean-Luc Nancy og af Ricoeur og Baders hermeneutik bliver de oldkirkelige dogmatiske begreber (homoousi, autologos) ikke længere, som man længe har ment, dét, der skal dekonstrueres, men snarere de begrebsdannelser, der selv indleder dekonstruktionen af fænomener, forestillinger og analogier (Nancy 2005, 219).

Men Luther er ikke den eneste, der tager Salmerne op i en bestemt stil, der ifølge Bader markerer tabet af en oprindelig forståelse. Før ham fremhæves en filosofisk og en musikalsk reception hos Nicolaus

29 For eksempel nr 3799, 1538 - Tischreden WA TR 3, 625, 19-26 (for henvisningen takkes ph.d.-studerende Kerstin Wimmer).

30 Ricoeur, "Lamentation as Prayer", Thinking Biblically (1998), 227.

31 Ricoeur, "Interpretive Narrative" (1995), 188, 191-199.

32 Ricoeur (1995), 199. For samme pointe se Ingolf U. Dalferth: "Selbstaufopferung. Vom Akt der Gewalt zur Passion der Liebe”, Umsonst, (Tübingen: Mohr Siebeck 2011), 152-155. 
Cusanus og Jean Gerson. De tre receptioner ved overgangen til den moderne erfaring af fremmedgørelse for Salmerne er paradigmatiske for Baders brug af metaforen "forstenede salmer", der først formuleres langt senere. ${ }^{33}$ Tænkning, teologi, kunst, poesi og musik reflekterer psalteret i forskellige stilistiske facetter og kunstarter, og spillet mellem disse fremviser det brudte forhold som efterklange af psalteret og som spor af dets forsvinden. For en tid kompenserer byggeriet af romanske kirker ganske vist for Salmernes forstummen. Kunstarterne udfolder det psalter-spil, som Bader hentyder til med sin titel, idet han samtidig med Luther minder om salmesprogets alvor (Bader 2009, 30). Spil betyder her et middel eller instrument, der er blevet et medium. Men strengelegen kan ikke skjule, at spillet samtidig viser sig at være en "øvelse i forsvinden". Bader skelner således mellem at lase og at samle som to forskellige måder at omgås med Salmerne på, der har kendetegnet deres reception. Læsningen slår over i samlingen af det spredte og overdragelsen heraf som et "bærbart fædreland" (Heinrich Heine). I selve det at samle sker et tab, en formindskelse af det indsamlede. Teksten/bogen bliver derved en "verden i verden", der ikke tilhører verden, men fordobler og transcenderer den. At Salmernes Bog således er overdraget som lasesalmer, markeres med Sl. 1, der indleder bogen med at prise den lykkelig, der "dag og nat" grunder på og glæder sig ved at lase Herrens lov: "Han er som et træ, der er plantet ved bækken, der bærer sin frugt til rette tid." (Bader 2009, \$1).

I samme periode, hvor Salmerne unddrager sig som sten og kunst, begynder Salmernes parallelistiske refleksionsstrukturer at tiltrække sig filosofisk og æstetisk opmærksomhed hos teologen Robert Lowth og hos filosoffen Johann Gottfried Herder: Von Geist der ebräischen Poesie (1782/1783). Indtil da havde de hebraiske salmer været frakendt enhver poetisk værdi i den europæiske kanon. Især blev den lange Salme 119 af mange med Schleiermacher anset for at være et vildtvoksende parallelisme-monster (Bader 2009, 424). Den femte tale i Scheleiermachers Reden (1799) udtrykker tidens afsmag for parallelisme som symptom på en jødisk bogstav- og gengældelsesteologi. I den samtidige filosofiske æstetik (Eduard Norden) formuleres fordommen mod parallelismens ørken-spøgelse under stikord som "africitet", "tumor Africus" (Bader 2009, 396). Overfor traditionelle nedvurderinger af navne-akrostik og parallelisme anfører

33 Metaforen 'forstenede salmer' blomstrer i romantikken og går her på sammenligningen med ottonske kirkebygninger. Bader henviser til Wilh. v. Kügelgen "Könnte ich Dir doch die alte Abteikirche in Gernrode aus dem 9t. Jahrhundert zeigen [...]. Es ist unbegreifflich, wie diese Alten [...] doch einen so überaus sublimen Geschmack haben konnten. Diese alten Kirchen sind versteinerten Psalmen.” Citeret fra Bader (2009), 89. 
Bader og Winfried Menningshaus, hvordan psalteret ikke bare har poetisk værdi, men at det bl.a. under indtryk af Herder har tilført afgørende impulser til de filosofiske systemudkast fra Fichte til Novalis, Friedrich Hölderlin og Hegel (Menningshaus 1987, 26f). Parallelismeteoriens indflydelse på den samtidige tyske filosofi og poesi er således også en afgørende forudsætning for den russiske formalisme hos Roman Jakobson, der netop anfører Novalis og Husserl som to afgørende inspirationskilder (Menningshaus 1987, 22). Men også poststrukturalister som Deleuze, Derrida og Niklas Luhmann skal ifølge Menningshaus ses i denne kontekst (Menningshaus 1987, 208223). Salmernes aktuelle potentiale fremgår således i Baders arbejde i feltet mellem strukturalisme og post-strukturalisme, hvortil den tyske idealisme udgør en baggrund. Salmernes teologiske betydning skal med andre ord søges gennem omvejen over den virkningshistorie, som Bader opsporer under overskriften "forstenede salmer". ${ }^{34}$

Med forsteningsmetaforen beskriver Bader en langstrakt "øvelse i forsvinding". Den arkitektoniske, musikalske, teologiske og filosofiske redning af psalteret, der begynder med den romanske kirkekunst, Cusanus, Gerson og Luther, afsluttes med Kant. Disse udsættelser kan ikke standse budskabet: at forstenede salmer ikke er en sublimeret affirmation. Stenen står for det negatives blivende overvægt over affirmationen (Bader 2009, 106). I første omgang forsvinder poesien og retorikken ind i musikken og begge ind i stenbyggeriet. Men selvom hver kunstart bevæger sig $\mathrm{i}$ et felt af relationer, kan de ikke undgå at blive trængte af opgaven at fremstille det absolutte. ${ }^{35} \mathrm{Hvad}$ der bliver tilbage er afskedstaler pace Schleiermacher og Kierkegaard. Men kan det afgørende reddes i talens form, som "talt religion" hos (den tidlige) Schleiermacher og Kierkegaard? Spændet mellem den poetiske og den prosaiske pol i Det Gamle Testamente og deres kryds-

34 Litho-teologi er en velkendt, men ifølge Bader ikke helt uproblematisk disciplin. Friedrich Ohly, Die Perle des Wortes (Frankfurt/M : Suhrkamp 2002), er den mest vidtløftige og upræcise "litho-poeto-teologi" (Bader 2009, 30). Et besøg i 2006 i stiftskirken Skt. Cyriakus i Gernrode, som Kügelgen henviser til (se note 33), gav ikke desto mindre Bader den afgørende impuls til at organisere 25 års salmelærdom under det tvivlsomme romantiske motiv "forstenede salmer". I en personlig kommunikation har Bader meddelt, at han anser $\$ 3$ "Das Verschwinden der Psalmen und die Psalterkunst" 87-128, der er viet til litho-teologien, for at været bogens svageste, dens "neuralgiske problem". Denne erkendelse viser imidlertid, at stenteologien - trods af Baders egen skepsis - har fungeret som en katalysator.

35 Bader (2008), 106: "Aber je mehr sie das Absolute darstellt, desto mehr entfernt sie sich von dieser Aufgabe. Erst in dem Mass, in dem sie in einer verwandten Kunst verschwindet, stellt sie das Masslose dar, das sie provoziert hat. Der Stein steht für das bleibende übergewicht der Negation über die Affirmation [...] So bleiben die versteinerten Psalmen der befremdliche, alle Relation übersteigende Hintergrund...”. 
ninger i Det Nye Testamente synes at være gået tabt i en pelagiansk voluntarisme, der kæmper med sin egen skygge. Hegels spekulative idealisme og N.F.S. Grundtvigs sublime gendigtninger fastholder heroverfor de formelle og teologiske udfordringer i psalteret.

\section{Navnets emergens og teologisk selvreference}

I værket Die Emergenz des Namens opridser Bader den religionsfilosofiske horisont, som værket Psalterspiel (2009) forudsætter. I det førstnævnte studie skriver Bader navnets teologi ind i en nutidig poststrukturalistisk religionsfilosofi hos Franz Rosenzweig, Emanuel Lévinas, Derrida, Don D. Caputo og med vigtige afsæt i Walter Benjamin og Geshom Sholem. Disse knytter til ved den klassiske jødiske og neo-platonske apofatiske teologi i traditionen fra Dionysios Areopagita, Maimonides, Meister Eckhart og Cusanus, som også optog de dannede i Luthers samtid. I Luthers anden salmeforelæsning 1519-21, Operationes in psalmos, går han ind på en diskussion af samtidens (for ham i første omgang irriterende) fascination af den apofatiske eller negative teologi, der kendetegner mystikken, og som han i lyset af Kristusåbenbaringen betragter som et pseudo-mysterium (Bader $2006, \$ 1,1-41)$. Ifølge Luthers kristne forudsætning er navnets hemmelighed åbenbaret eller ophævet med treenigheden som Fader, Søn og Helligånd. Alligevel indrømmer Luther her en længere ekskurs til spørgsmålet om navnet, hvori hemmeligheden tilkendes en vis vægt som baggrund for den kristne åbenbaring. Navnet er den transcendens, der har manifesteret sig i den kristne begivenhed, der ville miste sin karakter af (overraskende) begivenhed uden påmindelse om afgrundens dimension, der åbner sig i meditationen over navnets ubestemte hemmelighed (2 Mos 3, 14-15). Med navnets emergens sigter Bader i første omgang til denne indrømmelse, der fremtvinger sig en ekskurs i Luthers anden salmeforelæsning.

Baders hovedanliggende er dog navnets emergens - eller teologiens genkomst i filosofien - i den nutidige jødisk inspirerede filosofi (Rosenzweig, Lévinas, Derrida) på baggrund af strukturalismens "navnløse” parallelisme. Den sidstnævnte er indeholdt i Jakobsons mest citerede sentens: "enhver sproglig sekvens er en simile" (Bader 2011, 209; Menningshaus 1987, 8). Enhver sekvens er tillige en selvreferentiel fordobling (simile), der finder sted i de tre sprogfunktioner, som Jakobson kalder fatisk, metasproglig og poetisk, og som han skelner fra sprogets lineære (emotive, konative og referentielle) funktioner (Bader 2011, 209-210). Sekvensen refererer lineært til noget uden for sproget, mens similen er en sprogintern selvreference, og således kan Jakobson 
hævde, at sproget som helhed bygger på parallelisme og ikke kun poesien. Sprogets linearitet (sekvensen) krydses af similens tilbageløb, der således repræsenterer en cirkularitet, idet begge akser (alle seks funktioner) altid i større eller mindre grad er implicerede i enhver sproglig kommunikation. Sproget forløber således ifølge Jakobson ad to akser, den poetiske metaforiske pol, der svarer til similen, og den prosaiske og metonymiske pol, der svarer til sekvensen. Sproget er altid begge dele, men i forskellige grader, en krydsning mellem poesiens tværgående paradigmatiske og prosaens syntagmatiske lineære akse. ${ }^{36}$ Similen er ikke et billede af verden, men en verden i sprogets verden, omvendt er navnet i den bibelske navneteologi netop også en ren selvreference, "jeg er (den) jeg er." Det er forholdet mellem disse to indbyrdes uafhængige traditioner, den apofatiske tradition og den strukturelle lingvistik, som Bader kombinerer ud fra de måder navnets teologi fra tid til anden dukker op.

Navnets emergens går imidlertid også på erfaringen med ikke at kunne komme på et navn, der så pludseligt alligevel dukker op af glemslen. Også for denne teori støtter Bader sig til Jakobsons afhandlinger om afasi og sprog (Bader 2006, 192-232). Post-strukturalismens navne-emergens forudsætter således strukturalismens navnløse parallelisme hos især Jakobson, der formulerer teorien ud fra russisk folklore. Han markerer parallelismeteoriens absolutte højdepunkt efter de to grundlæggere Lowth og Herder, men her som nævnt uden berøring med navneteologien.

Omvendt dyrkes navnets teologi i den apofatiske teologi fra den nyplatonske Dionysios Areopagita og den jødiske Maimonides, men uden interesse for parallelismen (Bader 2011). Post-strukturalismen er en åbning imod den negative teologi. Her markeres navnets emergens under stikord som den Anden (Lévinas) eller i den (neo-)lacanianske psykoteologiske variant som "non/nom du père". I den post-strukturalistiske vending bevares blikket for det formelle abstraktionsniveau, som strukturalisme, systemteori og Lacans psykoanalyse har oparbejdet. Freuds enestående tiltro til "at jøderne ikke viger tilbage for sandhedens jordskælv" begrunder Lacan med, at jøden - efter tilbagekomsten fra Babylon - er den, "der kan læse. Dvs. han tager med bogstavet afstand fra sin tale, og finder dér, det interval, hvori han kan spille med en tydning." ${ }^{37}$ Den jødiske midrash tager bogen bogstaveligt, men ikke for at tillægge bogstavet skjulte eller åbenlyse intentioner, men i dets materialitet. Poststrukturalismens andethed

36 Krysdningspunktet er - oversat til teologiske begreber - korset, hvor Ordet ifølge logoskristologien gennemskæres af selvreferencen: autologos.

37 Jacques Lacan, "Radio", Radio - Fjernsyn/Radiophonie -Télévision (1970/1974) (København: politisk revy 1993), 41. 
spilles således ind i netværket af skrift og tekst, der ikke lader sig føre tilbage til fænomenologiens skriftløse intentionalitet. I dette krydsfelt belyser Bader spillet mellem poetisk parallelisme og navneteologi i traditionen.

I sin indflydelsesrige disputats Evangelische Evangelienauslegung. Eine Untersuchung zu Luthers Hermeneutik (1942) om Luthers første salme-forelæsning fra 1513-15 pegede Gerhard Ebeling på Luthers dekonstruktion af den traditionelle firfoldige bibeludlægning til fordel for en tautologisk udlægning, som titlen indikerer: "evangelisk evangelieudlægning”. Bader føjer nogle afgørende facetter til Ebelings Heidegger-inspirerede eksistentialhermeneutik, som den direkte Wort-Gottes-Theologie afskærer, når tiltalen og berørtheden her bliver den centrale analogi for syndsbevidsthed og retfærdiggørelse. Omvejen over tekstens symbolske netværk, som Ricoeur anbefaler, indeholder en tilsvarende kritik af Ebelings direkte påberåbelse af Guds tale gennem samvittighedens stemme. ${ }^{38}$ Skriftens gøren skal snarere forstås på linje med Freuds begreb om det ubevidste, der er indestruktibelt og tidløst, men utilgængeligt for bevidsthedens forsøg på at integrere skriften i talen, teksten i oversættelsen, ordet i den lyttendes samvittighed. Ricoeur er tilsvarende skeptisk overfor Ottmar Fuchs' opfattelse af, at gudsforladtheden skulle være det moderne menneskes umiddelbare, men oversete mulighed for at forstå sig selv i klagesalmen. ${ }^{39}$ Selvom Ricoeur er afgørende inspireret af Fuchs, skal intentionen i denne tilgang formidles gennem en litterærkritisk omvej over tekstens og skriftens egen gøren, dens polyfoni af genrer, som han efterlyser hos både Ebeling og Fuchs. Tesen om forstenede salmer er således et korrektiv til historiske rekonstruktioner og eksistentialistiske aktualiseringer. Salmernes "Sitz im Wort/Schrift" reaktualiseres for Ricoeur og Bader primært i læsningen "dag og nat" og ikke i tiltalen eller i rekonstruktioner af en oprindelig kultisk eller anden kontekst, som på forskellig vis har kendetegnet en historistisk og eksistentialistisk tilegnelses- og applicerings-hermeneutik. Heroverfor kan man med Bader tale om en eksistentiel lokalisering af salmestenen ikke i livet, men "ved livets rand" (Bader 2009, 30, 34). ${ }^{40}$

38 Ricoeur, "The Summoned subject in the School of the Narratives of the Prophetic Vocation" (1995), 273-275.

39 Ricoeur, "Lamentation as Prayer" i Thinking Biblically (1998), 230.

40 I Die Kirche am Rand. Vier Paradoxe im Hinblick auf die Martinskirche von Gomadingen (Rheinbach: CMZ-Verlag 2010), der er skrevet i anledning af 250året for bygningen af den kirke, hvor Bader var præst fra 1977-1995, giver han udtrykket "rand" en konkret (kirken ligger i landsbyens udkant) og metaforisk prægning. 


\section{Afffektive realitetsfordoblinger}

I Salmerne klager og lovsynger et menneskeligt jeg/vi i en henvendelse til et du. Jeget åbenbarer sig her som nævnt med den også på hebraisk usædvanlige formel "ani aani" som "jeg, arme/nedbøjede", mens modparten du'et er Jah eller Jahve, navnet, som anråbes i nøden og prises i jubelen: Hallelu-jah. Psalteret udspænder sig som en bro over kløften mellem jorden og himlen. Den er en "bridge over troubled water", hvis følelsesspekter omfatter hevn, ømhed, fortvivlelse, trøst, håb og sågar latter (Sl 126). Den affektive virkning fremhæves ofte, mens de geologiske, tektoniske og arki-tektoniske facetter af psalterets virkningshistorie sjældent bemærkes. For egen regning kunne man lade et moderne ingenieur-kunstnerisk værk Brooklyn Bridge, sin tids længste hængebro, være et aspekt af psalter-spillet. Således besynges broen i Hart Cranes digt, der lader broen låne en myte til Gud: "And of the curveship lend a myth to God" (Crane 2000, 44). I kraft af broens ophavsmand, den tyske emigrant John Augustus Roebling, der var elev og ven af Hegel, kan broen samtidig siges at materialisere den absolutte idealismes uendelige fordoblinger, der som fremført ovenfor har tættere bånd til de bibelske salmer, end det normalt antages. Gennem brevveksling med Roebling fik Hegel kendskab til den nye verden, som han betragtede som den fremtid, der var grænsen for hans egen åndsfilosofi, der kun tillod at erkende det forgangne og nutidige. At broen og dens arkitekt forbinder ham med den nye verden er tillige en erindring om, at det latinske ord for præst, pontifex, betyder pontem faciens..$^{41}$ Den fremtid, som unddrager sig fortællingen og begrebet, er netop teologiens domæne, der også ifølge Hegel omhandler det skjulte og fremtidige, der tematiseres i Markuspassionens midrash "Han er opstanden, han er ikke her, men er gået i forvejen til Galilæa, der vil I se ham, som jeg har sagt" (Mk $16,7){ }^{42}$

Sprog og skrift, stål og sten er medier for en affektiv og imaginær realitetsfordobling, der passerer igennem jegets nåleøje: "ani aani”, og som tillader at sammenligne en brokonstruktions stålwirer med Davids harpens "choiring strings". Broen materialiserer den "uendelige fordobling" (Hegel 1988, 127), der er konstituerende for den tidlige tyske romantik og idealisme. Indsigten i denne "autonome negations" grund i Bibelens poetiske parallelismeteknik forbliver imidlertid uerkendt eller direkte afvist som "tumor africus" (Eduard Norden) og hos Schleiermacher som jødisk gengældelsesteologi. Den tyske

41 For henvisningen til denne etymologi og til Hart Crane takkes cand.theol. Jan Masorsky.

42 Ricoeur, "Interpretive Narrative" (1995), 199. 
dannelseshumanismes miskendelse af den bibelske og teologiske forudsætning føres ifølge Jacob Taubes videre hos neo-idealismens store navn Dieter Henrich. ${ }^{43}$ På linje med Taubes lægger også Menningshaus afstand til den kritik af refleksionens fordoblinger, som Manfred Frank med henvisning til Henrich har rettet mod Derrida, Deleuze, Luhmann, Hegel og Ricoeur. Afvisningen af refleksionens fordoblinger hænger hos Henrich og Frank bl.a. sammen med underkendelsen af parallelismens og teologiens afgørende betydning for den tyske idealisme (Menningshaus 1987, 267-275). I deres neoidealistiske tolkning af den tidlige tyske romantik forlænger Henrich og Frank den klassiske europæiske poesis regelkanon ifølge hvilken, parallelismen betragtes som en handicappet, regelløs og kaotisk poesi (Bader 2009, 396).

Med de anførte synspunkter kan overdrivelsen i det traditionelle teologiske standpunkt forsvares, at hele Bibelen er indeholdt i Salmernes Bog, og at Passionsberetningerne, Loven og Profeterne følgelig er fortolkende fortællinger, midrash, der knytter sig til denne bøgernes bog (Bader 2009, 3). Det er blevet sagt om evangelierne, at de er passionsberetninger med lange indledninger (M.Kähler), og ifølge Bader er psalter-teologi i prægnant forstand kun mulig som kristologi i en restriktiv betydning nemlig som et guddommeligt selv-ord/autologos (Bader 2009, 411f.). Således kan Salme 22 kaldes en poetisk sammenfatning af kristendommen i Det Gamle Testamente. ${ }^{44}$ Modstemmen, den spørgende klage, i Salme 22, baner et nyt spor, der fører ud over en deuteronomistisk gengældelsesteologi, der med domsprofetiens doktrin om straf og skyld tendentielt bort-rationaliserer urlidelsens problem. Transcendensen og det ondes persisteren er således ifølge Ricoeur $(1995,199)$ den gåde, der vogtes af stensalmen indtil Påskemorgen, hvor stenen viser sig at være en juvel.

43 Jacob Taubes, Die politische Theologie des Paulus (München: Fink Verlag 1995), 13

44 André LaCocque, "Psalm 22”, Thinking Biblically (1998), 209. 